\title{
DZIAŁANIA WYCHOWAWCZO-EDUKACYJNE JAKO FORMA WSPARCIA ARESZTANTÓW I ARESZTANTEK NA TERENIE WOJEWÓDZTWA KRAKOWSKIEGO W CZASACH II RZECZYPOSPOLITEJ I ICH AKTUALNOŚĆ WE WSPÓŁCZESNEJ READAPTACJI SPOŁECZNEJ
}

Educational Activities as a Form of Support for Detainees in the Areas of the Cracow Voivodeship during the Second Republic of Poland and their Topicality in Detainee Contemporary Social Readaptation

S u m m a r y: Between 1918 and 1939 detainees were a group of people particularly vulnerable to marginalisation and social exclusion, which also concerned members of their families. The situation was aggravated by the fact that convicted persons most often came from families experiencing poverty and deprivation, and criminal behaviour was often the result of a difficult life situation which they experienced both in family and social life. Particularly difficult was the situation of the then women-detainees, as well as a significant number of orphans, living on the streets of cities, living off begging, petty thefts or robberies. The only chance of changing their life situation were assistance activities in the area of upbringing and education, which gave them the opportunity not only to improve their morality but often changed their lives by gaining education, work, as well as housing. The actions taken in many cases also concerned the children of detainees, their upbringing and education. The initiators of support for the detainees and their families were primarily charitable activities carried out by associations, societies, religious fraternities, actions taken by the court, prison staff and school teachers. Many of these aid initiatives can be seen in contemporary actions involving support for detainees and their families. It is extremely interesting that the same methods of educational impact and educational support are applied in the changed social reality today.

1 Dr hab. Barbara Nowak, prof. UP, Instytut Spraw Społecznych, Katedra Pomocy Postpenitencjarnej i Aktywizacji Zawodowej, os. Stalowe 17, 31-922 Kraków; e-mail: basianowak@onet.eu. 
Keywords: detainees, support, assistance activities, upbringing, education, poverty, the Archconfraternity of Mercy, St. Vincent a Paulo Association, Society for the Care of the Outcasts, Association of the Servants of St. Zita, Society of Cheap Housing, the Patronage (Society for the Care of Prisoners), lectures, talks about morality, social and educational work

\section{Wstęp}

W latach 1919-1922, kiedy trwała jeszcze walka o kształt granic i ustrój odradzającego się państwa polskiego, brak było właściwych mechanizmów ze strony państwa, które mogłyby mieć wpływ na podjęcie odpowiednich działań dotyczących przygotowania do życia wolnościowego aresztantów, z uwzględnieniem ich indywidualnych potrzeb.

Znaczne pozytywne zmiany $\mathrm{w}$ tym zakresie pojawiły się na przełomie lat 20. i 30. XX wieku, kiedy to wdrożono system oddziaływań ze strony państwa, jak również uporządkowano realizowane dotychczas w stosunku do więźniów działania pomocowe świadczone przez grupy dobroczynne.

Na obszarach ówczesnego województwa krakowskiego, utworzonego na podstawie ustawy z dnia 23 grudnia $1920 \mathrm{roku}^{2}$, struktura sądownictwa początkowo pozostała niezmieniona.

Równocześnie w większości funkcjonowały więzienia przejęte przez stronę polską na przełomie lat 1918 i $1919^{3}$.

W społeczeństwie II Rzeczypospolitej aresztanci i aresztantki stanowili grupę osób szczególnie narażoną na marginalizację i wykluczenie społeczne, co dotyczyło także członków ich rodzin. Sytuację pogarszał jeszcze fakt, że osoby skazane najczęściej pochodziły z rodzin doświadczających biedy, ubóstwa, a zachowania przestępcze były niejednokrotnie wynikiem ich trudnej sytuacji życiowej.

Szczególnie trudna pod tym względem była sytuacja ówczesnych aresztantek, wśród których znaczną grupę stanowiły służące, będące niejednokrotnie ofiarami

2 Ustawa $\mathrm{z}$ dnia 3 grudnia 1920 roku tymczasowej organizacji władz administracyjnych II instancji (województw) na obszarze b. Królestwa Galicji i Lodomerji z W. Ks. Krakowskiem oraz na wchodzących w skład Rzeczypospolitej Polskiej obszarach Spisza i Orawy, Dz.U. 1920, nr 117, poz. 768 ze zm. Rozporządzenie Rady Ministrów z dnia 17 maja 1921 r. w przedmiocie wykonania art. 3 ustawy z dnia 3 grudnia 1920 r. o tymczasowej organizacji władz administracyjnych II instancji (województw) na obszarze b. Królestwa Galicji i Lodomerji z W. Ks. Krakowskiem oraz na wchodzących w skład Rzeczypospolitej Polskiej obszarach Spisza i Orawy, Dz.U. 1921 r., nr 46, poz. 282.

3 Akta Sądu Krajowego Karnego w Krakowie z lat 1898-1918, Archiwum Narodowe w Krakowie (dalej: ANK), sygn. S7/2; zob. też Maciej Gondek, „Austriacka procedura karna z 1853 i 1873 roku w praktyce orzeczniczej sądów krakowskich”, Studia z Dziejów Państwa i Prawa Polskiego XVI (2013), 245-264; ostatecznie 1 stycznia 1919 roku Ministerstwo Sprawiedliwości przejęło administrację sądownictwa na obszarze dawnego zaboru austriackiego na podstawie Dekretu Naczelnika Państwa z dnia 31 grudnia 1918 roku, Dz.U. 1918, nr 23, poz. 76. 
nadużyć ze strony ich pracodawców i niemające możliwości sprawiedliwej obrony przed oskarżeniami, niekiedy niesłusznymi.

Drugą grupę stanowiły aresztantki pochodzące z ubogich wsi podkrakowskich, dla których znalezienie pracy w mieście było jedyną nadzieją na poprawę trudnej sytuacji życiowej, lecz brak wykształcenia, obycia z prawami obowiązującymi w społeczeństwach wielkomiejskich, sprawiał, że bardzo szybko wpadały w sidła działań przestępczych.

Wreszcie - inną grupą szczególnie narażoną na marginalizację były sieroty, żyjące na ulicach miast, utrzymujące się z żebractwa, drobnych kradzieży czy rozbojów ${ }^{4}$.

Trudna sytuacja społeczna wspomnianych osób mogła ulec zmianie jedynie poprzez odpowiednie wsparcie ze strony państwa czy też organizacji dobroczynnych, których rola w świadczeniu pomocy aresztantom była doniosła, szczególnie w pierwszych latach II Rzeczypospolitej.

\section{Działanie wychowawcze w obszarze wsparcia aresztantów i aresztantek}

Ważną rolę w działaniach pomocowych na rzecz aresztantów i aresztantek w czasach II Rzeczypospolitej odgrywały działania dobroczynne realizowane przez stowarzyszenia, towarzystwa, bractwa religijne, w których statut wpisana była posługa miłosierdzia właśnie tym osobom.

Wśród nich istotne znaczenie miały formy wsparcia realizowane przez powstały w tym czasie „Patronat”. Jego członkowie mogli pełnić swoją posługę z uwzględnieniem norm prawnych określonych w obowiązującym wówczas Regulaminie więziennym ${ }^{6}$. Wszelkie oddziaływania wychowawcze rozpoczynano od pracy nad kształtowaniem odpowiednich postaw moralnych aresztantów,

4 Barbara Nowak, Pomoc kobietom z nizin społecznych na terenie Krakowa (1918-1939) (Kraków: PETRUS, 2017), 101-125.

Jego działalność obejmowała „pracę w więzieniach, opiekę nad byłymi więźniami i rodzinami, pomoc dla kobiet i dziewcząt w Zakładzie w Krakowie przy ulicy Kasztelańskiej 24, obejmującym Dom Pracy dla Kobiet, Izbę Zatrzymań dla małoletnich przestępczyń, Pogotowie Opiekuńcze dziewcząt [...]". Sprawozdanie z działalności Patronatu w Krakowie (Towarzystwo Opieki nad Więźniami), za czas od 1 kwietnia 1925 do 31.03.1926, Kraków 1926. Sprawozdanie z działalności Patronatu w Krakowie (Towarzystwo Opieki nad Więźniami), za czas od 1 kwietnia 1938 do 31.03.1939, Kraków 1939; zob. też Barbara Nowak, Działania pomocowe w obszarze wsparcia ubogich kobiet-aresztantek na terenie Krakowa w czasach II Rzeczypospolitej (Gliwice: J\&L Żochowski, 2016).

6 „Członkowie Towarzystwa Patronatu Więziennego mogą odwiedzać więźniów po złożeniu pisemnego zezwolenia Ministerstwa Sprawiedliwości, w dnie i godziny, ustalone po uprzednim porozumieniu się z naczelnikiem więzienia. Przy odwiedzinach więźniów przez członków Patronatu ma być obecny naczelnik więzienia lub jego pomocnik. Dla odwiedzania więźniów śledczych niezbędne jest nadto zezwolenie właściwej władzy sądowej lub prokuratorskiej”. Regulamin więzienny, Rozdział I, $\$ 142$. 
przy czym posługiwano się przede wszystkim wzorcami osobowymi, których poszukiwano w literaturze polskiej, historii czy w religii (tabela 1).

Chodziło przede wszystkim o eliminowanie negatywnych zachowań, których źródłem było niejednokrotnie środowisko rodzinne aresztantów, wpływ środowiska przestępczego, w którym spędzili znaczną część swojego życia.

Tabela 1. Praca wychowawcza wśród aresztantów w latach 1923-1930 (wybrane przykłady)

\begin{tabular}{|c|c|c|c|c|}
\hline Rok & Miejsce & Formy wsparcia & $\begin{array}{c}\text { Cele podejmowanych } \\
\text { działań }\end{array}$ & $\begin{array}{c}\text { Osoby świadczące } \\
\text { pomoc }\end{array}$ \\
\hline 1923 & Kraków & $\begin{array}{l}\text { - nauka zasad higieny } \\
\text { osobistej, } \\
\text { - porady dotyczące } \\
\text { zdrowia, } \\
\text { - udział } \\
\text { w pogadankach } \\
\text { dotyczących } \\
\text { polskich władców } \\
\text { - wskazywanie na } \\
\text { ich bohaterstwo i } \\
\text { „miłosierdzie } \\
\text { w odnoszeniu się do } \\
\text { poddanych”, } \\
\text { - nauka stolarstwa. }\end{array}$ & $\begin{array}{l}\text { - nauka właściwego } \\
\text { zachowania się } \\
\text { w czasie spożywania } \\
\text { posiłków, } \\
\text { - nauka właściwego } \\
\text { zachowania w czasie } \\
\text { nabożeństw. }\end{array}$ & $\begin{array}{l}\text { Członkowie } \\
\text { Stowarzyszenia } \\
\text { św. Wincentego } \\
\text { a Paulo }\end{array}$ \\
\hline 1923 & Stary Sącz & $\begin{array}{l}\text { - udział w odczytach } \\
\text { dotyczących polskich } \\
\text { błogosławionych } \\
\text { i świętych, udział } \\
\text { w odczytach } \\
\text { dotyczących historii } \\
\text { Polski. }\end{array}$ & $\begin{array}{l}\text { - wskazywanie } \\
\text { zachowań „godnych do } \\
\text { naśladowania”. }\end{array}$ & $\begin{array}{l}\text { Członkowie } \\
\text { Arcybractwa } \\
\text { Miłosierdzia, } \\
\text { nauczyciele }\end{array}$ \\
\hline 1924 & Wieliczka & $\begin{array}{l}\text { - dostarczanie książek, } \\
\text { w szczególności } \\
\text { z literatury polskiej } \\
\text { i historii, } \\
\text { - udział w odczytach } \\
\text { na temat polskich } \\
\text { krain geograficznych, } \\
\text { ze szczególnym } \\
\text { podkreśleniem ich } \\
\text { piękna jako źródła } \\
\text { wrażeń estetycznych, } \\
\text { kształtujących uczucia } \\
\text { patriotyczne, } \\
\text { - nauka } \\
\text { odpowiedniego } \\
\text { zachowania w czasie } \\
\text { „nauki i odpoczynku”. }\end{array}$ & $\begin{array}{l}\text { - wzbudzanie } \\
\text { zainteresowania } \\
\text { wydarzeniami } \\
\text { z przeszłości Polski, } \\
\text { - kształtowanie uczuć } \\
\text { patriotycznych, } \\
\text { - wyrabianie } \\
\text { umiejętności } \\
\text { odpowiedniego } \\
\text { zachowania } \\
\text { w czasie wolnym, } \\
\text { ze szczególnym } \\
\text { zwróceniem uwagi na } \\
\text { bezpieczne } \\
\text { i trzeźwościowe formy } \\
\text { zachowania. }\end{array}$ & $\begin{array}{l}\text { Członkowie } \\
\text { Arcybractwa } \\
\text { Miłosierdzia, } \\
\text { nauczyciele }\end{array}$ \\
\hline
\end{tabular}




\begin{tabular}{|c|c|c|c|c|}
\hline 1924 & Dobczyce & $\begin{array}{l}\text { - dostarczanie książek, } \\
\text { w szczególności } \\
\text { z literatury polskiej } \\
\text { i historii, } \\
\text { - udział } \\
\text { w pogadankach } \\
\text { na temat } \\
\text { „chrześcijańskiego } \\
\text { życia: jak być dobrym } \\
\text { mężem i ojcem?”. }\end{array}$ & $\begin{array}{l}\text { - kształtowanie } \\
\text { odpowiednich postaw } \\
\text { moralnych w życiu } \\
\text { rodzinnym. }\end{array}$ & $\begin{array}{l}\text { Członkowie } \\
\text { Stowarzyszenia } \\
\text { św. Wincentego } \\
\text { a Paulo }\end{array}$ \\
\hline 1925 & Jaworzno & $\begin{array}{l}\text { - dostarczanie książek, } \\
\text { w szczególności } \\
\text { z literatury polskiej } \\
\text { i historii, a także } \\
\text { książeczek do } \\
\text { nabożeństwa, } \\
\text { - udział } \\
\text { w nabożeństwach. }\end{array}$ & $\begin{array}{l}\text { - kształtowanie } \\
\text { odpowiednich postaw } \\
\text { moralnych w życiu } \\
\text { społecznym. }\end{array}$ & $\begin{array}{l}\text { Członkowie } \\
\text { Stowarzyszenia } \\
\text { św. Wincentego } \\
\text { a Paulo, } \\
\text { nauczyciele }\end{array}$ \\
\hline 1925 & Limanowa & $\begin{array}{l}\text { - dostarczanie książek } \\
\text { religijnych, } \\
\text { - udział w odczytach } \\
\text { dotyczących tematyki } \\
\text { religijnej, } \\
\text { - udział w } \\
\text { pogadankach } \\
\text { dotyczących } \\
\text { „chrześcijańskiego } \\
\text { wychowania dzieci”. }\end{array}$ & $\begin{array}{l}\text { - kształtowanie } \\
\text { odpowiednich postaw } \\
\text { moralnych w życiu } \\
\text { rodzinnym, } \\
\text { - kształtowanie } \\
\text { odpowiednich postaw } \\
\text { rodzicielskich, } \\
\text { odpowiedzialności za } \\
\text { wychowanie } \\
\text { i kształcenie dzieci. }\end{array}$ & $\begin{array}{l}\text { Członkowie } \\
\text { Stowarzyszenia } \\
\text { św. Wincentego } \\
\text { a Paulo, } \\
\text { członkowie } \\
\text { „Patronatu” }\end{array}$ \\
\hline 1925 & Sucha & $\begin{array}{l}\text { - udział w odczytach } \\
\text { i uroczystościach } \\
\text { religijnych poza } \\
\text { aresztem. }\end{array}$ & $\begin{array}{l}\text { - wyrabianie } \\
\text { umiejętności } \\
\text { odpowiedniego } \\
\text { zachowania } \\
\text { w czasie nabożeństw } \\
\text { religijnych. }\end{array}$ & $\begin{array}{l}\text { Członkowie } \\
\text { Arcybractwa } \\
\text { Miłosierdzia }\end{array}$ \\
\hline 1926 & Jaworzno & $\begin{array}{l}\text { - nauka katechizmu, } \\
\text { przygotowanie do } \\
\text { chrztu i pierwszej } \\
\text { komunii świętej. }\end{array}$ & $\begin{array}{l}\text { - kształtowanie postaw } \\
\text { chrześcijańskiego } \\
\text { zachowania zarówno } \\
\text { w życiu społecznym, } \\
\text { jak i rodzinnym. } \\
\end{array}$ & $\begin{array}{l}\text { Członkowie } \\
\text { Arcybractwa } \\
\text { Miłosierdzia, } \\
\text { proboszcz parafii, } \\
\text { nauczyciel }\end{array}$ \\
\hline 1926 & $\begin{array}{l}\text { Czarny } \\
\text { Dunajec }\end{array}$ & $\begin{array}{l}\text { - nauka katechizmu, } \\
\text { przygotowanie do } \\
\text { chrztu, } \\
\text { - nauka czytania } \\
\text { i pisania, } \\
\text { - udział w odczytach } \\
\text { o tematyce religijnej. }\end{array}$ & $\begin{array}{l}\text { - kształtowanie } \\
\text { odpowiednich postaw } \\
\text { moralnych } \\
\text { w życiu społecznym } \\
\text { i rodzinnym. }\end{array}$ & $\begin{array}{l}\text { Członkowie } \\
\text { Stowarzyszenia } \\
\text { św. Wincentego } \\
\text { a Paulo }\end{array}$ \\
\hline
\end{tabular}




\begin{tabular}{|c|c|c|c|c|}
\hline 1926 & Wieliczka & $\begin{array}{l}\text { - dostarczanie } \\
\text { książek o tematyce } \\
\text { historycznej, religijnej, } \\
\text { - udział w odczytach } \\
\text { o tematyce religijnej, } \\
\text { - nauka katechizmu. }\end{array}$ & $\begin{array}{l}\text { - kształtowanie postaw } \\
\text { chrześcijańskiego } \\
\text { zachowania zarówno } \\
\text { w życiu społecznym, } \\
\text { jak i rodzinnym, } \\
\text { - wzbudzanie } \\
\text { w aresztantach } \\
\text { pragnienia poprawy } \\
\text { swojego życia poprzez } \\
\text { podjęcie wysiłków } \\
\text { w celu rozpoczęcia } \\
\text { nowego etapu życia, } \\
\text { opartego na uczciwości } \\
\text { i pracowitości. }\end{array}$ & $\begin{array}{l}\text { Członkowie } \\
\text { Stowarzyszenia } \\
\text { św. Wincentego } \\
\text { a Paulo, } \\
\text { członkowie } \\
\text { „Patronatu” }\end{array}$ \\
\hline 1926 & Kraków & $\begin{array}{l}\text { - dostarczanie książek } \\
\text { o tematyce religijnej,| } \\
\text { - udział } \\
\text { w uroczystościach } \\
\text { religijnych poza } \\
\text { aresztem, } \\
\text { - nauka katechizmu, } \\
\text { - przygotowanie do } \\
\text { pierwszej komunii } \\
\text { świętej, } \\
\text { - nauka pieśni } \\
\text { religijnych. }\end{array}$ & $\begin{array}{l}\text { - wzbudzanie } \\
\text { u aresztantów } \\
\text { zainteresowania } \\
\text { książkami religijnymi, } \\
\text { - poszukiwanie } \\
\text { wzorów wychowania } \\
\text { chrześcijańskiego } \\
\text { w książkach } \\
\text { religijnych. }\end{array}$ & $\begin{array}{l}\text { Członkowie } \\
\text { Stowarzyszenia } \\
\text { św. Wincentego } \\
\text { a Paulo }\end{array}$ \\
\hline 1927 & Sucha & $\begin{array}{l}\text { - dostarczanie } \\
\text { książek o tematyce } \\
\text { historycznej, religijnej, } \\
\text { - udział } \\
\text { w uroczystościach } \\
\text { religijnych poza } \\
\text { aresztem, } \\
\text { - udział w odczytach } \\
\text { o tematyce historycznej } \\
\text { na terenie aresztu. }\end{array}$ & $\begin{array}{l}\text { - wzbudzanie } \\
\text { u aresztantów } \\
\text { zainteresowania } \\
\text { książkami religijnymi, } \\
\text { - poszukiwanie } \\
\text { wzorów wychowania } \\
\text { chrześcijańskiego } \\
\text { w książkach } \\
\text { religijnych. }\end{array}$ & $\begin{array}{l}\text { Członkowie } \\
\text { Stowarzyszenia } \\
\text { św. Wincentego } \\
\text { a Paulo, } \\
\text { członkowie } \\
\text { „Patronatu” }\end{array}$ \\
\hline
\end{tabular}




\begin{tabular}{|c|c|c|c|c|}
\hline 1928 & Dobczyce & $\begin{array}{l}\text { - udzielanie wsparcia } \\
\text { duchowego, } \\
\text { - udział w odczytach } \\
\text { o tematyce } \\
\text { historycznej, } \\
\text { - nauka } \\
\text { odpowiedniego } \\
\text { spędzania czasu } \\
\text { wolnego, zapoznanie } \\
\text { z zasadami gier } \\
\text { zespołowych, } \\
\text { - udział w odczytach } \\
\text { dotyczących } \\
\text { przestrzegania prawa } \\
\text { Mojżeszowego, } \\
\text { spożywania pokarmów } \\
\text { w czasie zwykłym } \\
\text { i świątecznym, } \\
\text { zwrócenie uwagi } \\
\text { na ważność postu } \\
\text { w życiu człowieka } \\
\text { i konieczność jego } \\
\text { przestrzegania zgodnie } \\
\text { z wyznawaną religią. }\end{array}$ & $\begin{array}{l}\text { - kształtowanie postaw } \\
\text { chrześcijańskiego } \\
\text { zachowania zarówno } \\
\text { w życiu społecznym, } \\
\text { jak i rodzinnym, } \\
\text { - wskazywanie na } \\
\text { religię jako drogę } \\
\text { prowadzącą do } \\
\text { moralnego życia. }\end{array}$ & $\begin{array}{l}\text { Członkowie zboru } \\
\text { izraelskiego, } \\
\text { członkowie } \\
\text { „Patronatu” }\end{array}$ \\
\hline 1928 & Wieliczka & $\begin{array}{l}\text { - udział w odczytach } \\
\text { o tematyce religijnej, } \\
\text { - dostarczanie książek } \\
\text { o tematyce religijnej, } \\
\text { - udział w odczytach } \\
\text { dotyczących polskich } \\
\text { świętych } \\
\text { i błogosławionych. }\end{array}$ & $\begin{array}{l}\text { - kształtowanie postaw } \\
\text { moralnych za pomocą } \\
\text { literatury o tematyce } \\
\text { religijnej, } \\
\text { - zachęcanie do } \\
\text { naśladowania } \\
\text { wybranych postaci } \\
\text { świętych } \\
\text { i błogosławionych. } \\
\end{array}$ & $\begin{array}{l}\text { Członkowie } \\
\text { Stowarzyszenia } \\
\text { św. Wincentego } \\
\text { a Paulo i członkowie } \\
\text { „Patronatu” }\end{array}$ \\
\hline 1929 & Kraków & $\begin{array}{l}\text { - udział w odczytach } \\
\text { o tematyce religijnej, } \\
\text { - dostarczanie książek } \\
\text { o tematyce religijnej, } \\
\text { - udział w odczytach } \\
\text { dotyczących polskich } \\
\text { świętych } \\
\text { i błogosławionych, } \\
\text { - udział } \\
\text { w uroczystościach } \\
\text { religijnych } \\
\text { i państwowych poza } \\
\text { aresztem, } \\
\text { - przygotowanie do } \\
\text { sakramentów. }\end{array}$ & $\begin{array}{l}\text { - przygotowywanie } \\
\text { do życia na wolności } \\
\text { poprzez wychowanie } \\
\text { religijne } \\
\text { i „patriotyczne”, } \\
\text { - zachęcanie do } \\
\text { naśladowania } \\
\text { określonych wzorców } \\
\text { spośród osób } \\
\text { duchownych } \\
\text { i świeckich. }\end{array}$ & $\begin{array}{l}\text { Członkowie } \\
\text { Stowarzyszenia } \\
\text { św. Wincentego } \\
\text { a Paulo i członkowie } \\
\text { „Patronatu”, proboszcz } \\
\text { parafii }\end{array}$ \\
\hline
\end{tabular}




\begin{tabular}{|l|l|l|l|l|}
\hline 1930 & Kraków & - udział w odczytach & - zachęcanie & Członkowie \\
& & o tematyce religijnej, & aresztantów do & Arcybractwa \\
& & podejmowania & Miłosierdzia \\
w uroczystościach & wysiłków celem & i członkowie \\
religijnych na terenie & aresztu, a także poza & zmiany swojego & postępowania, \\
nim, & - watronatu” \\
- organizowanie & zainteresowania \\
pogadanek & literaturą o tematyce \\
dotyczących & religijnej, \\
zbliżających się rocznic & - kształtowanie uczuć \\
państwowych. & patriotycznych & \\
& & \\
\hline
\end{tabular}

Źródło: badania własne na podstawie następujących źródeł: Sądy różne zbiór szczątków zespołów, Akta Miasta Krakowa, ANK; nr zespołu 26; Akta i Księgi różne 1852-1934, w: ANK, sygn. Kr 4707-4827; Akta Miejskiego Urzędu Zdrowia 1910-1934, ANK, sygn. Kr 4090-4307; Komisariat obwodów IV i V, korespondencja przychodząca 1925-1935, ANK, sygn. Kr 5865; Szkoła więzienna i zatrudnienie więźniów, ANK, sygn. 29/440 /107; Żywienie więźniów wyznania mojżeszowego podczas świąt żydowskich przez zbór izraelski, ANK, sygn. 29/440/111; Podania ubogich o przyjęcie do Towarzystwa Dobroczynnego Krakowskiego z lat 1908-1932, ANK, sygn. TD 239; Sprawozdanie Towarzystwa kolonii leczniczych dla dzieci w Zakopanem za lata 1912-1916, Kraków 1914; Sprawozdanie z działalności Patronatu w Krakowie (Towarzystwo Opieki nad Więźniami), za czas od 1 kwietnia 1925 do 31.03.1926.

Powyższe badania źródłowe wskazują, iż działania mające na celu „poprawę" aresztantów zawierały w sobie wiele elementów wychowania, którego idee były realizowane wobec młodych pokoleń w warunkach wolnościowych. W latach 1918-1926 było to przede wszystkim wychowanie obywatelskie z mocnym akcentowaniem czynnika społecznego, narodowego i politycznego. Silnym fundamentem w pojęciu ówczesnej moralności były zasady etyki chrześcijańskiej, które kształtowały wartości ponadczasowe, takie jak: uczciwość, rzetelność, pracowitość, a także miłość bliźniego. Te wartości stały się pewnym punktem odniesienia wychowania moralnego aresztantów, o czym świadczy chociażby dostarczanie im literatury o charakterze religijnym, organizowanie w środowisku aresztu pogadanek, odczytów religijnych czy też próby „uporządkowania” ich życia religijnego poprzez przygotowywanie do sakramentów ${ }^{7}$.

Ważną rolę w procesie wychowania odgrywało wychowanie patriotyczne, którego celem było kształtowanie osobowości posiadającej określony stosunek

7 Leon Zarzecki, „O głównych postulatach wychowania narodowego”, Przegląd Wszechpolski 6 (1924), 471-472. 
do państwa, narodu; istotną rolę odgrywało kształtowanie światopoglądu i postawy godnej „miana Polaka”, postawy gotowej nawet do poświęceń dla państwa, jeśli taka byłaby konieczność ${ }^{8}$.W tym celu organizowano odczyty historyczne, podczas których odpowiednie osoby, jak chociażby sędziowie, nauczyciele szkół więziennych i innych szkół, proboszczowie parafii, zapoznawały aresztantów z życiorysami Polaków, których uważano za odpowiednie wzorce do naśladowania9 .

Podejmowane wśród aresztantów działania wychowawcze w kwestii kształtowania postaw patriotycznych pozostawały w tym samym nurcie wychowawczym, co wychowanie młodzieży w szkołach, stąd też w początkach II Rzeczypospolitej wielką wagę przywiązywano między innymi do wychowania obywatelskiego, propagującego konieczność wychowywania ludzi światłych, mających poczucie jedności z państwem i narodem, takich, którzy potrafiliby odnaleźć swoje miejsce w życiu społecznym ${ }^{10}$.

Z kolei w myśl haseł sanacji niezmiernie istotne było pojęcie dobra publicznego, które było priorytetowe wśród wartości narodowych. Podporządkowano mu więc wychowanie, które było adekwatne do konieczności wypełniania zadań w obszarze polityki, gospodarki, jak również kultury. Gwarancję niezależnego bytu dostrzegano właśnie w państwie, które jako jedyne było w stanie zapewnić warunki równomiernego rozwoju najwyższych dóbr duchowych człowieka ${ }^{11}$.

Biorąc pod uwagę powyższe ideały ówczesnego wychowania, celem pracy wychowawczej wśród aresztantów i aresztantek było wzbudzenie w nich owego poczucia „przynależności” do państwa, które jest w stanie pomóc im uzyskać zaufanie $\mathrm{w}$ społeczeństwie, pomimo kary aresztu, ale równocześnie oczekiwano od nich podjęcia wysiłku w zakresie pracy dla państwa. Przygotowanie do życia na wolności przez odpowiednie działania wychowawcze było rozumiane jako „praca nad dobrem i spokojem Państwa i społeczeństwa” ${ }^{2}$.

Realizowane postulaty wychowawcze miały mobilizować do pracy nad sobą, co miałoby swoje odzwierciedlenie w pełnej gotowości do pełnienia funkcji w życiu rodzinnym, zawodowym zgodnie z prawem państwa. Analiza ówczesnych źródeł przekonuje, iż szczególne formy pomocy poprzez aspekt wychowania kierowano do aresztantek. Poza oddziaływaniami, na które wskazano w przypadku aresztantów, istotnym celem zabiegów wychowawczych było odpowiednie

8 Szkoła więzienna i zatrudnienie więźniów, ANK, sygn. 29/440/107.

9 Tamże.

10 „Dla uratowania jednego człowieka warto poświęcić wiele - uratowanie przestępcy i uczynienie z niego dobrego obywatela i pożytecznej jednostki, to cel wielki [...]". Sprawozdanie z działalności Patronatu w Krakowie (Towarzystwo Opieki nad Więźniami), za czas od 1 kwietnia 1938 do 31.03.1939. Zob. Bogdan Nawroczyński, Polska myśl pedagogiczna (Lwów: Książnica - Atlas, 1938); por. też Ludwik. Malinowski, Wychowanie państwowe w Drugiej Rzeczypospolitej (Warszawa: Wydawnictwo Akademii Pedagogiki Specjalnej, 2015), 56.

11 Tamże, 57.

12 Sprawozdanie $z$ działalności Patronatu w Krakowie (Towarzystwo Opieki nad Więźniami), za czas od 1 kwietnia 1938 do 31.03.1939. 
przygotowanie ich do założenia rodziny, właściwego pełnienia funkcji żony i matki, a tym samym realizowania odpowiedzialnego powołania wobec państwa i społeczeństwa ${ }^{13}$. Istotne było również wskazanie im odpowiedniego „kierunku w dążeniu do poprawy" poprzez wzbudzanie pragnienia uczciwego życia po odbyciu kary, a wpojone uczucia patriotyczne miały stanowić solidną podstawę do podejmowanych wysiłków dla dobra ojczyzny, narodu i rodziny (tabela 2).

Tabela 2. Praca wychowawcza wśród aresztantek w latach 1923-1939 na terenie Krakowa (wybrane przykłady)

\begin{tabular}{|c|l|c|}
\hline Rok & \multicolumn{1}{|c|}{ Formy wsparcia } & \multicolumn{1}{|c|}{ Osoby świadczące pomoc } \\
\hline 1923 & $\begin{array}{l}\text { - dostarczanie książek o tematyce religijnej, } \\
\text { - porady prawne, } \\
\text { - udział w odczytach o tematyce religijnej } \\
\text { i historycznej, } \\
\text { - udział w pogadankach dotyczących odpowiedniego } \\
\text { przygotowania się do roli żony i matki. }\end{array}$ & $\begin{array}{l}\text { Członkinie Stowarzyszenia Sług } \\
\text { św. Zyty, członkinie „Patronatu” }\end{array}$ \\
\hline 1924 & $\begin{array}{l}\text { - udział w pogadankach na temat prawidłowej opieki } \\
\text { nad dziećmi, dbałości o ich higienę i odżywianie, } \\
\text { - nauka katechizmu, } \\
\text { - udział w odczytach o tematyce religijnej, } \\
\text { wskazywanie wzorów do naśladowania wśród } \\
\text { polskich kobiet - świętych i błogosławionych, } \\
\text { - udział w pogadankach na temat właściwego } \\
\text { zachowania przy wykonywaniu obowiązków } \\
\text { służących. }\end{array}$ & \\
\hline 1925 & $\begin{array}{l}\text { - udział w pogadankach dotyczących „zasad } \\
\text { moralnego prowadzenia się niezamężnych kobiet”, } \\
\text { zwrócenie uwagi na odpowiedni, skromny ubiór } \\
\text { kobiet, odpowiednie zachowanie się w urzędach, } \\
\text { w kościele i w miejscu pracy, } \\
\text { - udział w odczytach o tematyce religijnej, } \\
\text { - nauka katechizmu, } \\
\text { - przygotowanie do pierwszej komunii świętej. }\end{array}$ & $\begin{array}{l}\text { Członkinie Stowarzyszenia } \\
\text { św Wincentego a Paulo, } \\
\text { członkowie „Patronatu” }\end{array}$ \\
\hline 1926 & $\begin{array}{l}\text { - udział w pogadankach na temat opieki nad małymi } \\
\text { dziećmi, ich pielęgnacji, odżywiania i wychowania, } \\
\text { - organizowanie dla aresztantek nauki gotowania, } \\
\text { naprawy odzieży, szycia bielizny i ubranek dla dzieci. }\end{array}$ & Członkinie „Patronatu” \\
\hline
\end{tabular}

13 Podania ubogich o przyjęcie do Towarzystwa Dobroczynnego Krakowskiego z lat 1908-1932, ANK, sygn. TD 239 (prośby matek aresztantek o przyjęcie do Domu Ubogich). 


\begin{tabular}{|c|c|c|}
\hline 1926 & $\begin{array}{l}\text { - udział w pogadankach na temat „moralnego } \\
\text { prowadzenia się młodych kobiet” oraz „ważności } \\
\text { pracy w drodze do nieba”, } \\
\text { - udział w pogadankach na temat odpowiedniego } \\
\text { zachowania się w urzędach, o tym, jak właściwie } \\
\text { zachowywać się w miejscu pracy, } \\
\text { - przygotowywanie do sakramentów. }\end{array}$ & $\begin{array}{l}\text { Członkinie „Patronatu”, } \\
\text { kapelan więzienny }\end{array}$ \\
\hline 1927 & $\begin{array}{l}\text { - „praca nad poprawą i uszlachetnianiem } \\
\text { aresztantek”, } \\
\text { - udział w pogadankach na temat opieki, żywienia } \\
\text { i wychowania małych dzieci, } \\
\text { - przygotowanie aresztantki do chrztu, } \\
\text { - chrzest dzieci. }\end{array}$ & $\begin{array}{l}\text { Członkinie „Patronatu”, } \\
\text { proboszczowie }\end{array}$ \\
\hline 1932 & $\begin{array}{l}\text { - udział w pogadankach na temat opieki, żywienia, } \\
\text { higieny, wychowania małych dzieci, } \\
\text { - nauka katechizmu, } \\
\text { - udział w odczytach o tematyce religijnej, } \\
\text { - udział w pogadankach na temat „ważności pracy } \\
\text { w drodze do nieba”. }\end{array}$ & $\begin{array}{l}\text { Członkinie Bractwa św. Józefa, } \\
\text { członkinie „Patronatu” }\end{array}$ \\
\hline 1933 & $\begin{array}{l}\text { - udział w pogadankach na temat „moralnego } \\
\text { prowadzenia się młodych niezamężnych kobiet”, } \\
\text { - udział w odczytach na temat: „Wychowanie dzieci } \\
\text { dla ojczyzny i społeczeństwa”, } \\
\text { - uczestnictwo w uroczystościach upamiętniających } \\
\text { ważne wydarzenia państwowe, odbywających się na } \\
\text { terenie aresztu, } \\
\text { - spacery historyczne, zwiedzanie wybranych miejsc } \\
\text { w mieście celem wzbudzania w aresztantach uczuć } \\
\text { patriotycznych. }\end{array}$ & $\begin{array}{l}\text { Członkinie Bractwa św. Józefa, } \\
\text { członkinie „Patronatu”, } \\
\text { nauczyciele }\end{array}$ \\
\hline 1934 & $\begin{array}{l}\text { - udział w pogadankach na temat „moralnego } \\
\text { prowadzenia się młodych niezamężnych kobiet”, } \\
\text { - nauka katechizmu, } \\
\text { - udział w odczytach dotyczących historii, polskich } \\
\text { królów i książąt, wskazywanie przykładów do } \\
\text { naśladowania. }\end{array}$ & $\begin{array}{l}\text { Członkinie „Patronatu”, } \\
\text { członkowie Stowarzyszenia Sług } \\
\text { św. Zyty }\end{array}$ \\
\hline 1935 & $\begin{array}{l}\text { - nauka katechizmu, } \\
\text { - przygotowanie do pierwszej komunii świętej, } \\
\text { - udział w odczytach o tematyce religijnej, } \\
\text { - udział w odczytach na temat: „Służba Ojczyźnie”. }\end{array}$ & $\begin{array}{l}\text { Członkinie Arcybractwa } \\
\text { Miłosierdzia, } \\
\text { sędziowie }\end{array}$ \\
\hline
\end{tabular}




\begin{tabular}{|c|c|c|}
\hline 1936 & $\begin{array}{l}\text { - udział w pogadankach na temat opieki, żywienia } \\
\text { i wychowania dzieci, } \\
\text { - nauka katechizmu, } \\
\text { - nauka gospodarstwa domowego - poznawanie } \\
\text { zasad dobrego gospodarowania finansami w rodzinie, } \\
\text { - wskazywanie, jak radzić sobie w trudnych } \\
\text { sytuacjach życiowych, choroby, wojny, jak } \\
\text { przestrzegać obowiązującego prawa, jak postępować } \\
\text { w przypadku „nieuczciwego postępowania innych } \\
\text { członków rodziny [...] obywateli”. }\end{array}$ & $\begin{array}{l}\text { Członkinie „Patronatu”, } \\
\text { nauczyciele, } \\
\text { sędziowie }\end{array}$ \\
\hline 1936 & $\begin{array}{l}\text { - nauka katechizmu, } \\
\text { - nauka gospodarstwa domowego, podkreślanie } \\
\text { szczególnej roli kobiety w życiu państwa } \\
\text { i społeczeństwa, } \\
\text { - nauka pieśni patriotycznych, hymnu państwowego, } \\
\text { wyjaśnianie znaczenia słów „niezrozumiałych dla } \\
\text { aresztantek”. }\end{array}$ & $\begin{array}{l}\text { Członkinie „Patronatu”, } \\
\text { nauczyciele }\end{array}$ \\
\hline 1937 & $\begin{array}{l}\text { - udział w odczytach o tematyce dotyczącej } \\
\text { roli kobiet w wychowaniu młodych pokoleń, } \\
\text { wskazywanie przykładów do naśladowania wśród } \\
\text { kobiecych postaci historycznych, np. działaczek } \\
\text { społecznych, kobiet zaangażowanych w walkę } \\
\text { narodowo-wyzwoleńczą, zachęcanie do ich } \\
\text { naśladowania, } \\
\text { - organizowanie wycieczek o charakterze } \\
\text { historycznym (Wawel, kościół Świętych Piotra } \\
\text { i Pawła, wybrane pomniki Krakowa) w celu } \\
\text { wzbudzania uczuć patriotycznych. }\end{array}$ & $\begin{array}{l}\text { Członkinie „Patronatu”, } \\
\text { członkinie Stowarzyszenia } \\
\text { Opieka nad dziewczętami pw. } \\
\text { św. Józefa, } \\
\text { nauczyciele }\end{array}$ \\
\hline 1938 & $\begin{array}{l}\text { - udział w pogadankach dotyczących problemu } \\
\text { moralnego zachowania dziewcząt, } \\
\text { - dostarczanie książek o tematyce religijnej, } \\
\text { historycznej, dotyczących gospodarstwa domowego, } \\
\text { wychowywania dzieci w rodzinie, } \\
\text { - organizowanie prelekcji dotyczących obowiązków } \\
\text { obywateli wobec państwa i społeczeństwa, } \\
\text { wskazywanie na szczególną rolę kobiet w dziejach } \\
\text { państwa i narodu polskiego. }\end{array}$ & $\begin{array}{l}\text { Członkinie Stowarzyszenia Sług } \\
\text { św. Zyty, } \\
\text { członkinie Katolickiego } \\
\text { Stowarzyszenia Kobiet, } \\
\text { Sekcji Opieki nad Młodymi } \\
\text { Dziewczętami, } \\
\text { nauczyciele }\end{array}$ \\
\hline 1939 & $\begin{array}{l}\text { - udział w pogadankach dotyczących problemu } \\
\text { moralnego zachowania młodych matek, opieki nad } \\
\text { małym dzieckiem, żywienia i wychowania, } \\
\text { - udział w odczytach o tematyce historycznej, udział } \\
\text { w uroczystościach patriotycznych poza aresztem. }\end{array}$ & $\begin{array}{l}\text { Członkinie Katolickiego } \\
\text { Stowarzyszenia Kobiet, } \\
\text { członkinie Stowarzyszenia Sług } \\
\text { św. Zyty }\end{array}$ \\
\hline
\end{tabular}

Źródło: badania własne na podstawie następujących źródeł: Sądy różne zbiór szczątków zespołów, Akta Miasta Krakowa, ANK; nr zespołu 26; Akta i Księgi różne 1852-1934, ANK, sygn. Kr 47074827; Akta Miejskiego Urzędu Zdrowia 1910-1934, ANK, sygn. Kr 4090-4307; Komisariat obwodów IV i V, korespondencja przychodząca 1925-1935, ANK, sygn. Kr 5865; Szkoła więzienna i zatrudnienie więźniów, ANK, sygn. 29/440/107; Żywienie więźniów wyznania mojżeszowego podczas świąt żydowskich przez zbór izraelski; Podania ubogich o przyjęcie do Towarzystwa Dobroczynnego 
Krakowskiego z lat 1908-1932; Krakowskie zakłady poświęcone ochronie dzieci. Sprawozdanie biura Centralnego Związku Okręgowego Stowarzyszeń Zakładów i Instytucji poświęconych Ochronie Dzieci w Krakowie o stanie działalności Zakładów Dobroczynno-Wychowawczych istniejących w Krakowie i okolicy, Kraków 1915; Sprawozdanie Towarzystwa kolonii leczniczych dla dzieci w Zakopanem za lata 1912-1916; Sprawozdanie z działalności Patronatu w Krakowie (Towarzystwo Opieki nad Więźniami), za czas od 1 kwietnia 1925 do 31.03.1926; Cechy szewców w Krakowie, Kazimierzu i Kleparzu 1563-1925, ANK, nr zespołu 184, sygn. AD/DD; Sprawozdanie z działalności Stowarzyszenia Opieka nad dziewczętami pw. św. Józefa za czas od 1.IV.1937 do 31.03.1938, ANK, sygn. 151a/1938.

\section{Działania pomocowe w zakresie edukacji}

Analiza materiału źródłowego nie pozostawia wątpliwości co do faktu, iż znaczna grupa ówczesnych aresztantów i aresztantek nie posiadała umiejętności czytania i pisania, przez co podatność na popełnienie przestępstwa była w tej grupie o wiele większa niż u pozostałych osób.

Analfabetyzm towarzyszący ubóstwu, którego doświadczali, spychał ich jeszcze bardziej na margines życia społecznego.

Dla wielu z nich czas pobytu w areszcie był jedyną możliwością zetknięcia się $\mathrm{z}$ edukacją dzięki działaniom dobroczynnym, podejmowanym przez wspomniane już bractwa, stowarzyszenia czy towarzystwa, których członkowie podczas pełnienia posługi miłosierdzia wiele czasu poświęcali na naukę czytania i pisania wśród aresztantów ${ }^{14}$.

Powyższe działania w czasach II Rzeczypospolitej były działaniami współistniejącymi z nauką w szkołach więziennych, które funkcjonowały już na obszarach Galicji u schyłku XIX wieku, co w sposób obszerny przedstawia zachowany materiał źródłowy ${ }^{15}$. W tych szkołach edukacją zajmowali się nauczyciele pracujący również poza murami więziennymi; problemów przysparzał fakt, iż niewielu $\mathrm{z}$ nich chciało pracować $\mathrm{w}$ szkołach więziennych ${ }^{16}$. Edukacja dotyczyła różnych obszarów, była również urozmaicona pod względem stosowanych metod i form. Istotnym celem działań edukacyjnych było odpowiednie przygotowanie zarówno aresztantów, jak i aresztantek do życia na wolności poprzez zdobycie nowych umiejętności, które pomogłyby im właściwie funkcjonować w społeczeństwie (zob. tabela 3).

14 Regulamin więzienny, Rozdział II, Porządek dzienny, art. 107. „W okresie czasu między apelem wieczornym, a udaniem się więźniów na spoczynek, należy zająć ich nauką (o ile ta nie może się odbywać we dnie), lekturą, ćwiczeniami fizycznymi, rozrywkami umysłowymi, albo zatrudniać ich tak, jak podczas wypoczynku poobiedniego".

15 Nauka więźniów za rok 1899, Sprawozdania Sądów Powiatowych, ANK, sygn. 29/440/107. Sprawozdanie z dnia 3 lutego 1890 roku dotyczące nauki więźniów tutejszego Sądu Krajowego, ANK, sygn. 29/440/107.

16 Tamże. 
Tabela 3. Obszary edukacji realizowane wśród aresztantów i aresztantek w latach 1918-1939 (wybrane przykłady)

\begin{tabular}{|c|c|c|c|c|}
\hline Rok & Miejsce & Formy edukacji & $\begin{array}{l}\text { Uczestnicy } \\
\text { aresztanci/ } \\
\text { aresztantki }\end{array}$ & Uwagi \\
\hline 1918 & $\begin{array}{l}\text { Dobczyce, } \\
\text { Jaworzno, Sucha, } \\
\text { Czarny Dunajec, } \\
\text { Gorlice, Stary Sącz }\end{array}$ & Nauka religii & $\begin{array}{l}\text { Aresztanci } \\
\text { i aresztantki }\end{array}$ & $\begin{array}{l}\text { W wielu miejscach } \\
\text { pojawiały się } \\
\text { trudności ze } \\
\text { „znalezieniem” } \\
\text { księży do nauki } \\
\text { religii w aresztach }\end{array}$ \\
\hline \multirow[t]{3}{*}{1919} & $\begin{array}{l}\text { Kraków, Dobczyce, } \\
\text { Jaworzno, Sucha, } \\
\text { Czarny Dunajec, } \\
\text { Gorlice, Stary Sącz, } \\
\text { Bochnia }\end{array}$ & Nauka religii & $\begin{array}{l}\text { Aresztanci } \\
\text { i aresztantki }\end{array}$ & \\
\hline & $\begin{array}{l}\text { Kraków, Dobczyce, } \\
\text { Jaworzno, Sucha, } \\
\text { Czarny Dunajec, } \\
\text { Gorlice, Stary Sącz, } \\
\text { Bochnia }\end{array}$ & $\begin{array}{l}\text { Nauka czytania } \\
\text { i pisania }\end{array}$ & $\begin{array}{l}\text { Aresztanci } \\
\text { i aresztantki }\end{array}$ & \\
\hline & Kraków & $\begin{array}{l}\text { Odczyty } \\
\text { historyczne }\end{array}$ & $\begin{array}{l}\text { Aresztanci } \\
\text { i aresztantki }\end{array}$ & \\
\hline \multirow[t]{5}{*}{1920} & Kraków & $\begin{array}{l}\text { Pogadanki na } \\
\text { temat prowadzenia } \\
\text { gospodarstwa } \\
\text { domowego } \\
\text { (gotowanie, pranie, } \\
\text { szycie bielizny) }\end{array}$ & Aresztantki & $\begin{array}{l}\text { Edukacją } \\
\text { zajmowały się } \\
\text { członkinie } \\
\text { Stowarzyszenia } \\
\text { św. Wincentego } \\
\text { a Paulo }\end{array}$ \\
\hline & $\begin{array}{l}\text { Kraków, Dobczyce, } \\
\text { Jaworzno, Sucha, } \\
\text { Czarny Dunajec, } \\
\text { Gorlice, Stary Sącz, } \\
\text { Bochnia, Skawina }\end{array}$ & Nauka religii & $\begin{array}{l}\text { Aresztanci } \\
\text { i aresztantki }\end{array}$ & \\
\hline & $\begin{array}{l}\text { Kraków, Dobczyce, } \\
\text { Jaworzno, Sucha, } \\
\text { Czarny Dunajec, } \\
\text { Gorlice, Stary Sącz, } \\
\text { Bochnia, Skawina }\end{array}$ & $\begin{array}{l}\text { Nauka czytania } \\
\text { i pisania, nauka } \\
\text { rachunków }\end{array}$ & $\begin{array}{l}\text { Aresztanci } \\
\text { i aresztantki }\end{array}$ & \\
\hline & Kraków & $\begin{array}{l}\text { Nauka biologii } \\
\text { (dotyczyło wiedzy } \\
\text { potrzebnej do } \\
\text { pielęgnacji ogrodu) }\end{array}$ & $\begin{array}{l}\text { Aresztanci } \\
\text { i aresztantki }\end{array}$ & \\
\hline & Kraków & $\begin{array}{l}\text { Nauka robót } \\
\text { ręcznych }\end{array}$ & Aresztantki & $\begin{array}{l}\text { Nauka odbywała się } \\
\text { w każdy czwartek, } \\
\text { edukacją zajmowały } \\
\text { się członkinie } \\
\text { Arcybractwa } \\
\text { Miłosierdzia }\end{array}$ \\
\hline
\end{tabular}




\begin{tabular}{|c|c|c|c|c|}
\hline 1921 & $\begin{array}{l}\text { Kraków, Dobczyce, } \\
\text { Jaworzno, Sucha, } \\
\text { Czarny Dunajec, } \\
\text { Gorlice, Stary Sącz, } \\
\text { Bochnia, Skawina }\end{array}$ & Nauka religii & $\begin{array}{l}\text { Aresztanci } \\
\text { i aresztantki }\end{array}$ & $\begin{array}{l}\text { W edukację } \\
\text { angażowali się } \\
\text { członkowie } \\
\text { Arcybractwa } \\
\text { Miłosierdzia }\end{array}$ \\
\hline & & $\begin{array}{l}\text { Nauka czytania } \\
\text { i pisania, } \\
\text { rachunków }\end{array}$ & Aresztanci & $\begin{array}{l}\text { Członkinie } \\
\text { Stowarzyszenia } \\
\text { św. Wincentego } \\
\text { a Paulo }\end{array}$ \\
\hline \multirow[t]{3}{*}{1924} & $\begin{array}{l}\text { Kraków, Stary Sącz, } \\
\text { Bochnia, Skawina }\end{array}$ & $\begin{array}{l}\text { Nauka czytania } \\
\text { i pisania, } \\
\text { rachunków }\end{array}$ & Aresztantki & \\
\hline & Kraków & $\begin{array}{l}\text { Nauka prowadzenia } \\
\text { gospodarstwa } \\
\text { domowego } \\
\text { (gotowania, prania, } \\
\text { szycia, dbania } \\
\text { o ogród, } \\
\text { naprawy odzieży) }\end{array}$ & Aresztantki & \\
\hline & $\begin{array}{l}\text { Bochnia, Skawina, } \\
\text { Jaworzno }\end{array}$ & $\begin{array}{l}\text { Nauka „naprawy } \\
\text { obuwia, }[\ldots] \\
\text { wyrobu mebli } \\
\text { do gospodarstwa } \\
\text { domowego }[\ldots] ”\end{array}$ & Aresztanci & \\
\hline \multirow[t]{3}{*}{1929} & Kraków & $\begin{array}{l}\text { Nauka sztuki } \\
\text { kowalstwa }\end{array}$ & Aresztanci & \\
\hline & Kraków & $\begin{array}{l}\text { Nauka prowadzenia } \\
\text { gospodarstwa } \\
\text { domowego, } \\
\text { rachunków (co } \\
\text { dotyczy wydawania } \\
\text { pieniędzy), szycia } \\
\text { bielizny, prostych } \\
\text { ubrań (?), nauka } \\
\text { podstaw higieny }\end{array}$ & Aresztantki & $\begin{array}{l}\text { Członkinie } \\
\text { Stowarzyszenia } \\
\text { św. Wincentego } \\
\text { a Paulo }\end{array}$ \\
\hline & $\begin{array}{l}\text { Skawina, Czarny } \\
\text { Dunajec, Stary Sącz }\end{array}$ & $\begin{array}{l}\text { Nauka czytania, } \\
\text { pisania i nauka } \\
\text { rachunków }\end{array}$ & Aresztanci & \\
\hline 1932 & $\begin{array}{l}\text { Kraków, Dobczyce, } \\
\text { Jaworzno, Sucha, } \\
\text { Czarny Dunajec, } \\
\text { Stary Sącz, Bochnia }\end{array}$ & $\begin{array}{l}\text { Nauka czytania, } \\
\text { pisania i nauka } \\
\text { rachunków }\end{array}$ & $\begin{array}{l}\text { Aresztanci } \\
\text { i aresztantki }\end{array}$ & \\
\hline
\end{tabular}




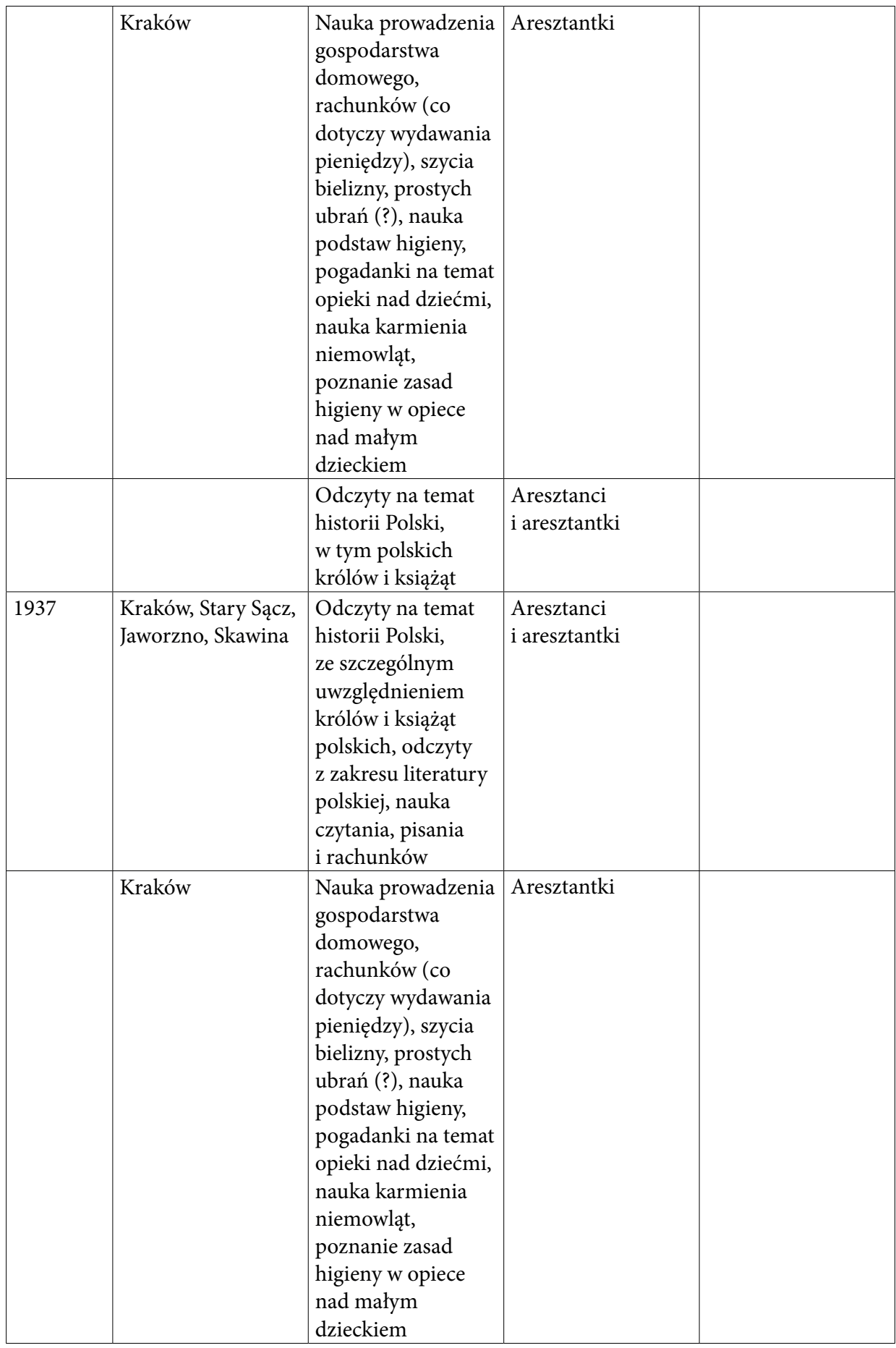




\begin{tabular}{|c|c|c|c|}
\hline & & $\begin{array}{l}\text { Nauka stolarstwa, } \\
\text { nauka posługiwania } \\
\text { się miarą i wagą } \\
\text { w handlu, „nauka } \\
\text { rachunków } \\
\text { przydatnych } \\
\text { w handlu” }\end{array}$ & Aresztanci \\
\hline & & $\begin{array}{l}\text { Nauka recytacji } \\
\text { wierszy polskich } \\
\text { poetów: Reja, } \\
\text { Kochanowskiego, } \\
\text { Morsztyna, } \\
\text { Krasickiego - } \\
\text { wielcy polscy poeci }\end{array}$ & $\begin{array}{l}\text { Aresztanci } \\
\text { i aresztantki }\end{array}$ \\
\hline 1938 & Kraków & $\begin{array}{l}\text { Nauka czytania, } \\
\text { pisania i rachunków }\end{array}$ & $\begin{array}{l}\text { Aresztanci } \\
\text { i aresztantki }\end{array}$ \\
\hline & & $\begin{array}{l}\text { Odczyty } \\
\text { historyczne na } \\
\text { temat polskiej } \\
\text { literatury }\end{array}$ & $\begin{array}{l}\text { Aresztanci } \\
\text { i aresztantki }\end{array}$ \\
\hline & & $\begin{array}{l}\text { Nauka historii } \\
\text { z uwzględnieniem } \\
\text { zabytków }\end{array}$ & $\begin{array}{l}\text { Aresztanci } \\
\text { i aresztantki }\end{array}$ \\
\hline & Kraków & $\begin{array}{l}\text { Wycieczka na } \\
\text { Wawel }\end{array}$ & $\begin{array}{l}\text { Aresztanci } \\
\text { i aresztantki }\end{array}$ \\
\hline & Kraków & $\begin{array}{l}\text { Poznawanie } \\
\text { polskiej kultury } \\
\text { poprzez odczyty } \\
\text { na temat rozwoju } \\
\text { polskiego } \\
\text { malarstwa }\end{array}$ & $\begin{array}{l}\text { Aresztanci } \\
\text { i aresztantki }\end{array}$ \\
\hline 1939 & $\begin{array}{l}\text { Skawina, Jaworzno, } \\
\text { Sucha, Stary Sącz }\end{array}$ & $\begin{array}{l}\text { Nauka religii, nauka } \\
\text { czytania, pisania } \\
\text { i rachunków }\end{array}$ & $\begin{array}{l}\text { Aresztanci } \\
\text { i aresztantki }\end{array}$ \\
\hline & Kraków & $\begin{array}{l}\text { Nauka biologii } \\
\text { i geografii „na } \\
\text { potrzeby poznania } \\
\text { polskich krain } \\
\text { geograficznych” }\end{array}$ & Aresztanci \\
\hline & Kraków & $\begin{array}{l}\text { Poznawanie } \\
\text { polskiej kultury } \\
\text { poprzez odczyty } \\
\text { na temat rozwoju } \\
\text { polskiego teatru }\end{array}$ & $\begin{array}{l}\text { Aresztanci } \\
\text { i aresztantki }\end{array}$ \\
\hline & Kraków & $\begin{array}{l}\text { Nauka szycia, } \\
\text { haftowania i innych } \\
\text { robót ręcznych }\end{array}$ & Aresztantki \\
\hline
\end{tabular}




\begin{tabular}{|l|l|l|l|}
\hline & $\begin{array}{l}\text { Nauka } \\
\text { „prowadzenia } \\
\text { gospodarstwa } \\
\text { domowego } \\
\text { przydatna } \\
\text { służącym” }\end{array}$ & Aresztantki & $\begin{array}{l}\text { W edukację były } \\
\text { zaangażowane } \\
\text { członkinie } \\
\text { Stowarzyszenia } \\
\text { Sług św. Zyty } \\
\text { i Stowarzyszenia } \\
\text { Opieka nad } \\
\text { młodymi } \\
\text { dziewczętami } \\
\text { pw. św. Józefa }\end{array}$ \\
\hline
\end{tabular}

Źródło: badania własne na podstawie następujących źródeł: Szkoła więzienna i zatrudnienie więźniów, ANK, sygn. 29/440/107; Szkoła więzienna i zatrudnienie więźniów, ANK, sygn. 29/440/111; Zakupienie nowych miar $i$ wag dla tut. Domu Karnego, ANK, sygn. 29/440/110; Sprawozdanie $z$ działalności Patronatu w Krakowie (Towarzystwo Opieki nad Więźniami), za czas od 1 kwietnia 1938 do 31.03.1939.

\section{Odzwierciedlenie dawnych działań pomocowych w aktualnych inicjatywach wychowawczo-edukacyjnych na rzecz osadzonych}

Pomimo przemian społeczno-politycznych, gospodarczych i kulturalnych na przestrzeni dziejów wciąż aktualna jest realizacja zadań pomocowych na rzecz osadzonych poprzez podejmowane działania wychowawcze i edukacyjne. Tak jak w minionym czasie, stanowią one dla nich szansę na zmianę swojej sytuacji życiowej przez zdobycie wiedzy w zakresie kultury życia codziennego, jak również przez uzupełnienie edukacji, zarówno tej podstawowej, jak i w zakresie szkolnictwa średniego, zdobycie kolejnych kwalifikacji poprzez udział w licznych kursach zawodowych, które są realizowane w jednostkach penitencjarnych.

Wciąż aktualna jest edukacja historyczna, w której poszukuje się wzorców do naśladowania, jak również staje się ona źródłem wychowania obywatelskiego.

Podejmowane działania pomocowe posiadają również aspekt wychowawczy w kwestii odpowiedzialnego rodzicielstwa, co dotyczy zarówno kobiet, jak i mężczyzn. Dzięki nim w wielu przypadkach udaje się naprawić zaburzone relacje rodzicielskie (tabela 4$)^{17}$.

17 Barbara Nowak, Marcin. Szymczyk, Przygotowanie do życia poza murami więziennymi poprzez działania kulturalno-oświatowe $w$ jednostkach penitencjarnych $i w$ warunkach wolnościowych (Kraków: Katedra Pomocy Postpenitencjarnej i Aktywizacji Zawodowej Uniwersytetu Pedagogicznego w Krakowie, 2019). 
Tabela 4. Współczesne (2018-2020) inicjatywy wychowawczo-edukacyjne w jednostkach penitencjarnych na terenie Okręgowego Inspektoratu Służby Więziennej w Krakowie i Okręgowego Inspektoratu Służby Więziennej w Rzeszowie (wybrane przykłady)

\begin{tabular}{|c|c|}
\hline $\begin{array}{l}\text { Podejmowane działania wychowawczo- } \\
\text {-edukacyjne na rzecz osadzonych }\end{array}$ & Jednostka penitencjarna \\
\hline $\begin{array}{l}\text { Zajęcia biblioteczne, zachęcanie do } \\
\text { czytelnictwa i zapoznanie z propozycjami } \\
\text { warsztatowymi proponowanymi w ofertach } \\
\text { edukacyjnych bibliotek }\end{array}$ & Areszt Śledczy w Krakowie \\
\hline $\begin{array}{l}\text { Zwiedzanie podziemi krakowskiego Rynku } \\
\text { Głównego }\end{array}$ & Areszt Śledczy w Krakowie \\
\hline Świąteczny koncert kwartetu smyczkowego & Areszt Śledczy w Krakowie \\
\hline $\begin{array}{l}\text { „Małe bożonarodzeniowe radości w tle } \\
\text { więziennej codzienności”, } \\
\text { spotkanie osadzonych kobiet z siostrami } \\
\text { Albertynkami, posługującymi ubogim }\end{array}$ & Areszt Śledczy w Krakowie \\
\hline $\begin{array}{l}\text { „Spotkanie z Mikołajem”, spotkanie } \\
\text { mikołajkowe skazanych z ich dziećmi }\end{array}$ & Areszt Śledczy w Krakowie \\
\hline $\begin{array}{l}\text { „Osadzeni pomagają podopiecznym z domu } \\
\text { pomocy społecznej” }\end{array}$ & Areszt Śledczy w Krakowie \\
\hline Wyjazd do Sanktuarium w Częstochowie & Areszt Śledczy w Krakowie \\
\hline $\begin{array}{l}\text { Skazani z rodzinami w Kopalni Soli } \\
\text { w Wieliczce }\end{array}$ & Areszt Śledczy w Krakowie \\
\hline Wyjazd do Muzeum Auschwitz-Birkenau & Areszt Śledczy w Krakowie \\
\hline $\begin{array}{l}\text { „Zaczytani w Zakładzie Karnym w Krakowie - } \\
\text { Nowej Hucie”, promocja czytelnictwa wśród } \\
\text { osadzonych }\end{array}$ & Zakład Karny w Nowej Hucie \\
\hline Aktywizacja zawodowa młodych osadzonych & Zakład Karny w Nowej Hucie \\
\hline Realizacja projektu: „Praca szansą dla młodych” & Zakład Karny w Nowej Hucie \\
\hline „Kultura pomimo ograniczeń i ciemności” & Zakład Karny w Nowej Hucie \\
\hline „Widzenie szkolne w wiśnickim CKU” & Zakład Karny w Nowym Wiśniczu \\
\hline Obchody 450-lecia podpisania Unii Lubelskiej & Zakład Karny w Nowym Wiśniczu \\
\hline Kontynuacja nauki w CKU & Zakład Karny w Nowym Wiśniczu \\
\hline „Uczczono święto Konstytucji 3 Maja” & Zakład Karny w Nowym Wiśniczu \\
\hline $\begin{array}{l}\text { „Realizacja projektu: Edukacja historyczna } \\
\text { w służbie resocjalizacji” }\end{array}$ & Zakład Karny w Rzeszowie \\
\hline $\begin{array}{l}\text { „Wielokulturowe Podkarpacie" - zajęcia } \\
\text { w ramach pracy kulturalno-oświatowej }\end{array}$ & Zakład Karny w Rzeszowie \\
\hline $\begin{array}{l}\text { „Drogi do Niepodległości - 100-lecie } \\
\text { Niepodległości” }\end{array}$ & Zakład Karny w Rzeszowie \\
\hline $\begin{array}{l}\text { „Żydowska szkoła Masada - Dni Pamięci } \\
\text { o ofiarach Holocaustu” }\end{array}$ & Zakład Karny w Rzeszowie \\
\hline
\end{tabular}

Źródło: www.gov.pl/aktualnosci_promowane/areszt-sledczy-w-krakowie (dostęp: 15.04.2020); www.sw.gov.pl/aktualnosc/Kultura (dostęp: 15.04.2020); https://sw.gov.pl/nodes/nodes/index/ page:4/type:aktualnosci/slug:zaklad-karny-w-rzeszowie (dostęp: 15.04.2020); https://sw.gov.pl/ aktualnosc/zaklad-karny-w-rzeszowie-wielokulturowe-podkarpacie (dostęp: 15.04.2020); https:// sw.gov.pl/nodes/nodes/index/page:5/type:aktualnosci/slug:zaklad-karny-w-nowym-wisniczu (dostęp:15.04.2020). 


\section{Zakończenie}

Realizacja postulatów wychowawczo-edukacyjnych w więziennej rzeczywistości umożliwiała osobom pozbawionym wolności właściwe ukierunkowanie ich planów życiowych już po opuszczeniu izolacji poprzez zdobycie nowych niezbędnych „narzędzi”.

Wśród nich wymienić należy przede wszystkim zdobycie wykształcenia, dodatkowych kwalifikacji, co znacznie miało ułatwić im zatrudnienie w warunkach wolnościowych. Inne „narzędzia” to zdobycie umiejętności w zakresie odpowiedniego funkcjonowania $\mathrm{w}$ życiu społecznym, przyjęcie norm zachowania zgodnych z obowiązującymi prawami, wreszcie ukształtowanie swej tożsamości, mocno umiejscowionej w konkretnym narodzie i państwie, poprzez zdobycie wiedzy na temat historii państwa, narodu w trakcie edukacji historycznej.

Jeszcze innym istotnym „narzędziem” było zdobycie określonych umiejętności organizowania życia rodzinnego, opieki nad dziećmi, żywienia, troski o zdrowie własne i innych domowników, uzyskanie informacji dotyczących przestrzegania zasad higieny, wpływających na zdrowy tryb życia.

Powyższe działania wychowawczo-edukacyjne, realizowane na rzecz aresztantów i aresztantek w czasach II Rzeczypospolitej, były podejmowane przede wszystkim w ramach działań pomocowych, a ich cenną wartością jest fakt „przetrwania” wielu z nich we współczesnej readaptacji społecznej osadzonych.

Streszcze n i e: W latach 1918-1939 aresztanci stanowili grupę osób szczególnie narażoną na marginalizację i wykluczenie społeczne, co dotyczyło także członków ich rodzin. Sytuację pogarszał jeszcze fakt, że osoby skazane najczęściej pochodziły z rodzin doświadczających biedy, ubóstwa, a zachowania przestępcze były niejednokrotnie wynikiem trudnej sytuacji życiowej, której doświadczali zarówno w życiu rodzinnym, jak i społecznym. Szczególnie trudna była sytuacja ówczesnych aresztantek, jak również rzeszy sierot żyjących na ulicach miast, utrzymujących się z żebractwa, drobnych kradzieży czy rozbojów. Jedyną szansą na zmianę ich sytuacji życiowej były działania pomocowe w obszarze wychowania i edukacji, które dawały im możliwość nie tylko poprawy moralnej, ale niejednokrotnie odmieniały ich życie poprzez zdobycie wykształcenia, pracy, jak również mieszkania. Podejmowane działania w wielu przypadkach dotyczyły też dzieci aresztantów, ich wychowania i edukacji. Wsparciem aresztantów i ich rodzin były przede wszystkim działania dobroczynne realizowane przez stowarzyszenia, towarzystwa, bractwa religijne, działania podejmowane przez pracowników sądowych, więziennych i nauczycieli szkół. Wiele z tych inicjatyw pomocowych można zaobserwować we współczesnych działaniach obejmujących wsparcie osadzonych i ich rodzin. Niezmiernie interesujące jest, iż współcześnie, w zmienionej już rzeczywistości społecznej znajdują zastosowanie między innymi te same metody oddziaływania wychowawczego i wsparcia edukacyjnego. 
Słowa kluczowe: aresztanci, wsparcie, działania pomocowe, wychowanie, edukacja, bieda, ubóstwo, Arcybractwo Miłosierdzia, Stowarzyszenie św. Wincentego a Paulo, Towarzystwo Opieki nad Podrzutkami, Stowarzyszenie Sług św. Zyty, Towarzystwo Tanich Mieszkań, Patronat (Towarzystwo Opieki nad Więźniami), odczyty, pogadanki o moralności, praca społeczno-oświatowa

\section{Bibliografia}

Źródła rękopiśmienne:

Akta i Księgi różne 1852-1934, sygn. Kr 4707-4827.

Akta i protokoły kapituł prowincjalnych oraz narad definitorium, akta w sprawach jurysdykcyjnych, współdziałania z innymi zakonami, pisma kurii generalnej, kopiarze i rejestry pism dotyczące prowincji małopolsko-litewskiej, galicyjskiej i polskiej z lat 1682-1937. W: Archiwum OO. Karmelitów w Krakowie, sygn. A169/AKKr 103.

Akta Miejskiego Urzędu Zdrowia 1910-1934. W: Archiwum Narodowe w Krakowie (ANK), sygn. Kr 4090-4307.

Akta Sądu Krajowego Karnego w Krakowie z lat 1898-1918. W: Archiwum Narodowe w Krakowie (ANK), sygn. S7/2.

Cechy szewców w Krakowie, Kazimierzu i Kleparzu 1563-1925. W: Archiwum Narodowe w Krakowie (ANK), nr zespołu 184, sygn. AD/DD.

Dekret Naczelnika Państwa z dnia 31 grudnia 1918 roku, w przedmiocie objęcia zarządu wymiaru sprawiedliwości w b. zaborze austrjackim, Dz.U. 1918, nr 23, poz. 76.

Ustawa z dnia 3 grudnia 1920 roku tymczasowej organizacji władz administracyjnych II instancji (województw) na obszarze b. Królestwa Galicji i Lodomerji z W. Ks. Krakowskiem oraz na wchodzących w skład Rzeczypospolitej Polskiej obszarach Spisza i Orawy, Dz.U. 1920, nr 117, poz. 768 ze zm.

Rozporządzenie Rady Ministrów z dnia 17 maja 1921 r. w przedmiocie wykonania art. 3 ustawy z dnia 3 grudnia 1920 r. o tymczasowej organizacji władz administracyjnych II instancji (województw) na obszarze b. Królestwa Galicji i Lodomerji z W. Ks. Krakowskiem oraz na wchodzących w skład Rzeczypospolitej Polskiej obszarach Spisza i Orawy, Dz.U. 1921, nr 46, poz. 282.

Komisariat obwodów IV i V, korespondencja przychodząca 1925-1935. W: Archiwum Narodowe w Krakowie (ANK), sygn. Kr 5865.

Podania ubogich o przyjęcie do Towarzystwa Dobroczynnego Krakowskiego z lat 1908-1932. W: Archiwum Narodowe w Krakowie (ANK), sygn. TD 239.

Sądy różne zbiór szczątków zespołów. W: Archiwum Narodowe w Krakowie (ANK), Akta Miasta Krakowa, nr zespołu 26.

Sprawozdanie Towarzystwa kolonii leczniczych dla dzieci w Zakopanem za lata 1912-1916, Kraków 1914.

Sprawozdanie z działalności Stowarzyszenia Opieka nad dziewczętami pw. św. Józefa za. W: Archiwum Narodowe w Krakowie (ANK), sygn. 157a/1937.

Szkoła więzienna i zatrudnienie więźniów. W: Archiwum Narodowe w Krakowie (ANK), sygn. 29/440/107.

Szkoła więzienna i zatrudnienie więźniów. W: Archiwum Narodowe w Krakowie (ANK), sygn. 29/440/111.

Zakupienie nowych miar $i$ wag dla tut. Domu Karnego. W: Archiwum Narodowe w Krakowie (ANK), sygn. 29/440/110. 
Żywienie więźniów wyznania mojżeszowego podczas świąt żydowskich przez zbór izraelski. W: Archiwum Narodowe w Krakowie (ANK), sygn. 29/440/111.

Źródła drukowane:

Hoszowski, Konstanty Moroz. „O środkach skutecznie zapobiec mogących żebractwu w mieście naszym”. W: Pamiętnik Towarzystwa Dobroczynności Krakowskiego wydany z powodu obchodzonego $w$ dniu 24 i 25 czerwca 1866 r. pięćdziesięcioletniego jubileuszu wskrzeszenia w r. 1816 tegoż Towarzystwa, Kraków 1868.

Krakowskie zakłady poświęcone ochronie dzieci. Sprawozdanie Biura Centralnego Związku Okręgowego Stowarzyszeń Zakładów i Instytucji poświęconych Ochronie Dzieci w Krakowie o stanie działalności Zakładów Dobroczynno-Wychowawczych istniejących w Krakowie i okolicy, Kraków 1915.

Rozporządzenie Ministra Sprawiedliwości z dnia 20 czerwca 1931 r. w sprawie regulaminu więziennego (Dz.U. 1931, nr 71, poz. 577), na podstawie art. 71 Rozporządzenia Prezydenta Rzeczypospolitej z dnia 7 marca 1928 roku w sprawie organizacji więziennictwa (Dz.U. 1928, nr 29, poz. 272).

Spraw. Towarzystwa Opieki Szpitalnej dla Dzieci w Krakowie wraz z sprawozdaniami Szpitala św. Ludwika i kolonii leczniczej dla dzieci skrofulicznych w Rabce za lata 1872-1916, Kraków 1917.

Sprawozdanie Towarzystwa kolonii leczniczych dla dzieci w Lwowie za lata 1911-1912, Lwów 1912.

Sprawozdanie z działalności Patronatu w Krakowie (Towarzystwo Opieki nad Więźniami), za czas od 1 kwietnia 1925 do 31.03.1926, Kraków 1926.

Sprawozdanie z działalności Patronatu w Krakowie (Towarzystwo Opieki nad Więźniami), za czas od 1 kwietnia 1938 do 31.03.1939, Kraków 1939.

www.gov.pl/aktualnosci_promowane/areszt-sledczy-w-krakowie (dostęp: 15.04.2020).

\section{Literatura:}

Gondek, Maciej. „Austriacka procedura karna z 1853 i 1873 roku w praktyce orzeczniczej sądów krakowskich". Studia z Dziejów Państwa i Prawa Polskiego XVI (2013).

Malinowski, Ludwik. Wychowanie państwowe w Drugiej Rzeczypospolitej. Warszawa: Akademia Pedagogiki Specjalnej, 2015.

Nawroczyński, Bogdan Polska myśl pedagogiczna. Lwów: Książnica - Atlas, 1938.

Nowak, Barbara. Działania pomocowe w obszarze wsparcia ubogich kobiet-aresztantek na terenie Krakowa w czasach II Rzeczypospolitej. Gliwice: J\&L Żochowski, 2016.

Nowak, Barbara. Pomoc kobietom z nizin społecznych na terenie Krakowa (1918-1939). Kraków: PETRUS, 2017.

Nowak, Barbara, Szymczyk, Marcin. Przygotowanie do życia poza murami więziennymi poprzez działania kulturalno-oświatowe $w$ jednostkach penitencjarnych $i w$ warunkach wolnościowych. Kraków: Katedra Pomocy Postpenitencjarnej i Wychowania do Pracy Uniwersytetu Pedagogicznego w Krakowie, 2019.

Zarzecki Leon. „O głównych postulatach wychowania narodowego”. Przegląd Wszechpolski 6 (1924). 